\title{
CREST Syndrome - a Limited Form of Systemic Scleroderma: a Case Report and Literature Review
}

\author{
Mirjana PARAVINA ${ }^{1}$, Milenko STANOJEVIĆ ${ }^{1}$, Ljiljana SPALEVIĆ ${ }^{1},{ }^{2}$, \\ Dragana LJUBISAVLJEVIĆ ${ }^{2}$, Zorana ZLATANOVIĆ ${ }^{2}$, Danijela POPOVIĆ ${ }^{2}$ \\ ${ }^{1}$ Medical Faculty, University of Niš, Serbia \\ ${ }^{2}$ Clinic of Skin and Venereal Diseases, Clinical Center of Nišs, Serbia2 \\ "Correspondence: Mirjana Paravina, E-mail: mirjanaparavina@gmail.com \\ UDC 616.5-004-07/-08 \\ UDC 616.5-004-092
}

\section{DE GRUYTER OPEN}

\begin{abstract}
Systemic scleroderma (SSc) is a multisystem disease with microvascular abnormalities, autoimmune disorders, excessive collagen production and deposition, and fibrosis of the skin and internal organs. According to the simplest, though incomplete classification, there are two forms of SSc: diffuse and limited (formerly acrosclerosis). CREST syndrome is a subtype of limited SSc, characterized by: calcinosis, Raynaud's phenomenon, esophageal dysfunction, sclerodactyly, and telangiectasia. We present a patient with all the features of the CREST syndrome, which appeared at the age of 43 and lasted for 23 years. The patient presented with a gradual development of symptoms during the first ten years, from Raynaud's phenomenon, skin sclerosis, calcinosis, telangiectasia, and esophageal dysmotility. The diagnosis was based on clinical findings and relevant diagnostic procedures. The article presents a literature review on the epidemiology, etiology, pathophysiology, clinical manifestations, various attempts at classification, diagnostic criteria, and therapeutic modalities.

When classifying systemic scleroderma into two main types - diffuse and limited, with CREST syndrome as a variant of the latter, it should be pointed out that both types represent clinical forms of systemic sclerosis, share similar visceral involvement, laboratory abnormalities and course which is variable, as was the case in our patient.
\end{abstract}

\section{Key words}

Scleroderma, Systemic; CREST Syndrome; Signs and Symptoms; Diagnosis

Systemic scleroderma (SSc) is a multisystem disease $\checkmark$ with microvascular abnormalities, autoimmune disorders, excessive collagen production and deposition, fibrosis of skin and internal organs, with progressive course and potentially fatal outcome (1, $2,3,4)$.

Due to a wide variety of clinical manifestations, common resemblance or co-occurrence with other connective tissue diseases, attempts to develop an adequate classification have been made for years. In 1962, Tuffanelli and Winkelmann proposed three forms of scleroderma based on skin involvement and severity: 1. acrosclerosis, 2. diffuse scleroderma, and 3. acute diffuse scleroderma (5). In 1978, based on his experience, Barnett suggested three subsets: 1. sclerodactyly; 2. sclerosis limited to the forearms, without trunk involvement; and 3. diffuse skin involvement, including the trunk (6). In 1979, Rodnan and associates made a distinction between diffuse scleroderma and CREST syndrome (7). In 1980, Giordano et al. described four types of systemic sclerosis (SS): 1. no skin involvement (no scleroderma); 2. limited systemic cutaneous sclerosis (limited systemic scleroderma); 3. intermediate systemic cutaneous sclerosis (intermediate systemic scleroderma); 4. diffuse systemic cutaneous sclerosis (diffuse systemic scleroderma) (8). In 1988, LeRoy et al. proposed the simplest classification of systemic sclerosis: diffuse cutaneous SS (diffuse systemic scleroderma), and limited cutaneous SS (limited systemic scleroderma) (9).

In 1980, the Subcommittee for Scleroderma of the American Rheumatism Association (ARA) defined diagnostic and therapeutic criteria for the 
classification of SSc (10), differentiating acral systemic scleroderma, or sclerodactyly and proximal systemic scleroderma; the single major criterion is scleroderma proximal to the digits, affecting the limbs, face, neck or trunk; or at least two minor criteria such as sclerodactyly or digital pitted scarring or bilateral basal pulmonary fibrosis. In 1996, the Committee of the American Academy of Dermatology proposed a comprehensive classification of cutaneous sclerosis in three large groups: A. primary cutaneous sclerosis, which includes diffuse systemic or limited systemic (CREST syndrome), localized or circumscribed without involvement of internal organs, part of the overlap syndrome (mixed and poorly differentiated connective tissue disease) and eosinophilic faciitis; B. secondary cutaneous sclerosis as a result of GVHD (graft versus host disease), use of medications, intoxication, infection; C. prodromal cutaneous sclerosis syndromes, primarily Raynaud's phenomenon (11). Apart from diffuse and limited systemic cutaneous sclerosis, in 2001, LeRoy and Medsger described also ectopic calcinosis and telangiectasias and limited unclassified prescleroderma, the so-called pre-systemic scleroderma (12). They introduced new criteria, including nailfold capillary microscopic abnormalities and the presence of autoantibodies, in order to establish patients with early limited systemic sclerosis without skin involvement. It is also called SS without skin involvement, visceral sclerosis, or SS sine scleroderma $(13,14)$.

In 2004, Maricq and Walter selected the following criteria for the classification of systemic sclerosis (SS): 1. sclerodermatous skin involvement; 2. microvascular abnormalities specific to SSc: SDtype nailfold capillary changes and/or CREST-type capillary telangiectasia; 3 . presence of anticentromere antibodies (ACA) (14). Based on these criteria they proposed the following classification:

I Diffuse sclerosis (all three criteria)

II Intermediate sclerosis (2 criteria)

III Digital sclerosis (one criterion)

IV Sclerosis without skin involvement (none of the criteria)

V Insufficiently differentiated connective tissue disease with sclerosis (one or none of the criteria)

VI CREST (one or none of the criteria).
In 2007, Walker et al. adapted the LeRoy and Medsger classification which included the following types: limited systemic scleroderma, limited systemic scleroderma with cutaneous involvement, diffuse systemic scleroderma and diffuse fasciitis with eosinophilia (15).

Scleroderma spectrum disorders involve the existence of the following (16):

1. diffuse systemic sclerosis;

2. limited cutaneous systemic sclerosis with CREST syndrome as a variation;

3. systemic sclerosis sine scleroderma;

4. localized scleroderma with linear scleroderma;

5. mixed connective tissue disease with features of systemic sclerosis, polymyositis, and SLE.

6. overlap syndromes: systemic sclerosis plus polymyositis, rheumatoid arthritis, or SLE.

7. scleroderma mimics - amyloidosis, chronic graftversus-host disease, diffuse fasciitis with eosinophilia, eosinophilia-myalgia syndrome, nephrogenic fibrosing dermopathy, paraneoplastic syndromes, scleredema, scleromyxedema (papular mucinosis), toxic oil syndrome;

8. undifferentiated connective tissue disease: multiple nonspecific, serologic or clinical abnormalities that do not meet ACR (American College of Rheumatology) criteria for rheumatic disease.

We report a patient with limited systemic scleroderma - CREST syndrome.

\section{Case Report}

A female patient, 66 years of age, first noticed skin changes at the age of 43 . They progressed during the following $10-15$ years, but after that time, they mostly persisted unchanged, with occasional bacterial and fungal secondary infections. The disease lasted for 23 years, and resulted in fatal outcome at the age of 66. In the last eleven years, she was hospitalized several times.

The first symptoms appeared on the acral areas of hands which were cold, turning white, purple then red. At first, the attacks were cold induced, later they became more frequent, regardless of the temperature, involving the toes as well. In the following two years, these were the only symptoms of the disease, but later the fingers got pale, hard, with impaired mobility, 
subsequently leading to inability to fully stretch them, which significantly affected activities of daily living. The nails became thin and fragile. The skin of the distal portions of the arms and legs became thinner and tight. The involvement of the face started five years after the appearance of first symptoms; facial skin also became tight, thin and hard, without wrinkles. The face became smaller, wrinkles were prominent around the mouth, whereas dry mouth caused difficulties when smiling, laughing, talking or chewing food. Then, firm yellowish nodules developed on the finger joints, as well as large solid nodules on the shoulders and thighs. At that time, the patient started experiencing difficulties swallowing, heartburn, and regurgitation after large meals. No other organ involvement was reported.

The patient reported no serious illnesses. There was no family history of a similar condition.

\section{Physical examination}

Upon skin examination, the skin was pale, yellowish in color, thight, smooth, taut, and mask like. The face got smaller, with radial furrows around the mouth, causing the skin to stretch so that the few residual teeth were visible due to gingival retraction. The beaked nose and deep-sunken eyes have contributed to a typical "birdlike" face (Figure 1). The fingers were semiflex, very sclerotic, cold ("Madonna fingers"), tapered at the ends, with shortened distal phalanges, and apparent shortening of thinned nail plates (Figure 1). The dorsal sides of hands presented with small calcifications over the joints, above which the skin was paper thin and pale yellowish in color. Blotchy hyperpigmentation and telangiectasias were also present. The skin of the lower legs and feet exhibited similar characteristics, with pronounced telangiectasias in the form of spots or dark red lacy lines, with cyanosis, hypo- and hyper-pigmentation, and scars, while the nail plates were thickened (Figure 2). The interdigital areas were pesented with madidation and maceration, erythema, erosions and scaling due to secondary fungal infection. Both sides of the gluteal areas were affected by infiltrates with inflamed skin and fluctuation. There

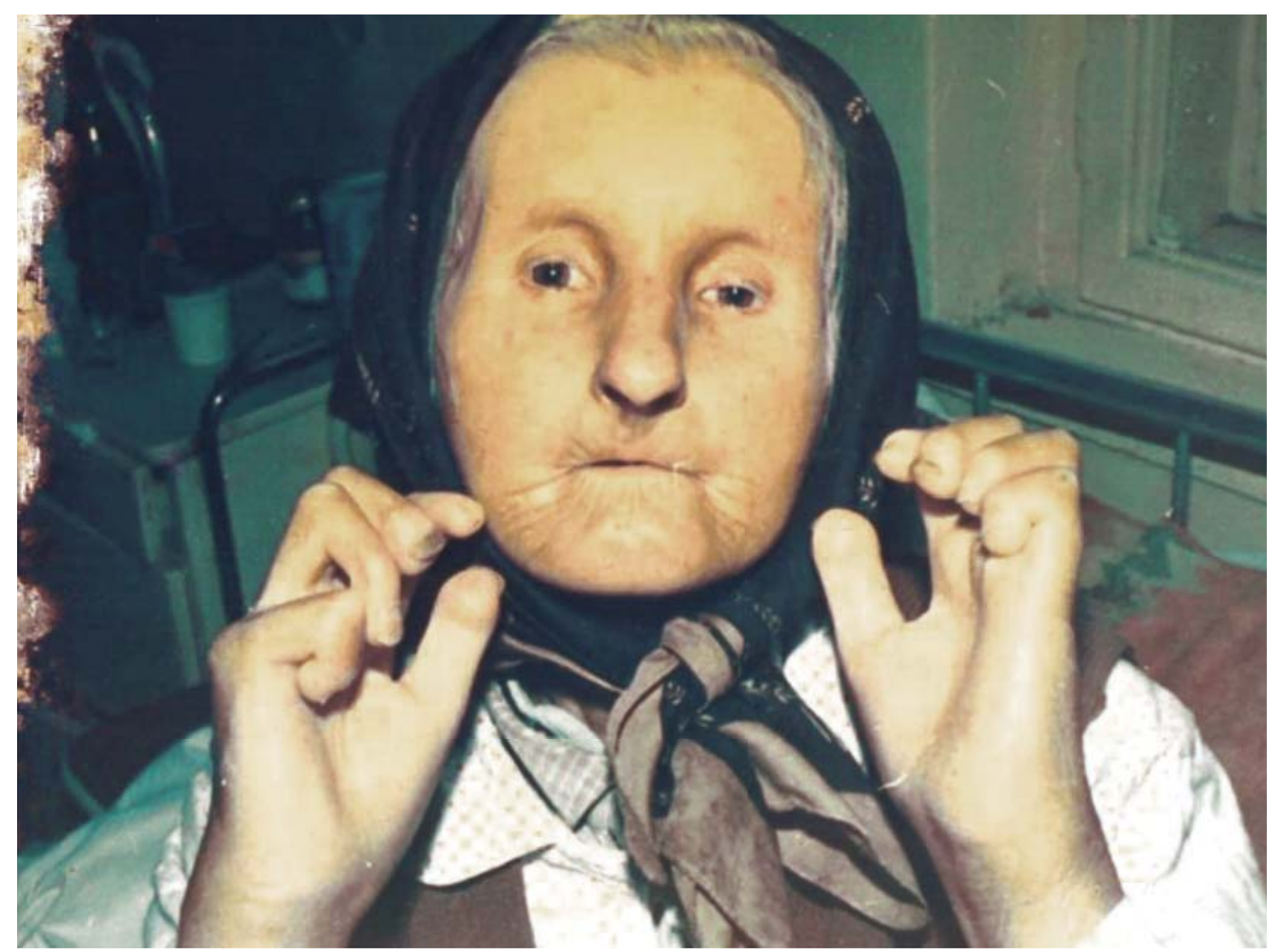

Figure 1. The face is tightening; the skin is thin, with radial furrows around the mouth, mask-like and expressionless. The fingers are semiflex, very sclerotic, with shortened distal phalanges, and apparent shortening of thinned nail plates 


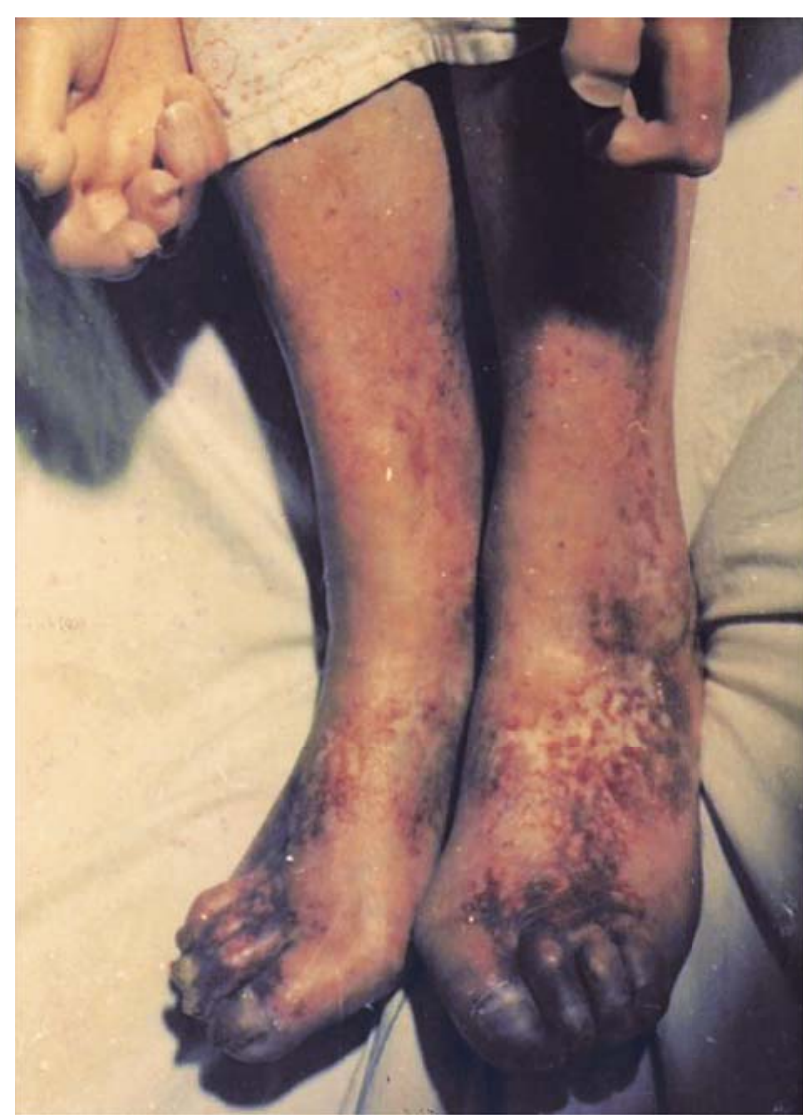

Figure 2. The skin of the lower legs and feet is thin, with pronounced telangiectasias in the form of spots or dark red lacy lines, with cyanosis, scars and nail abnormalities

was a lesion secreting mucus and blood at pressure or spontaneously, and a chalky white material. After surgical intervention, the pseudofistula was closed, but in the area of the gluteus, indurations in the size of a walnut were palpable. The skin of the lower arms, upper arms and the trunk was affected to a lesser extent. Calcifications were present on the left shoulder with a tendency to secretion (Figure 3).

\section{Laboratory and other test results}

Laboratory investigations revealed the following abnormal tests: erythrocyte sedimentation rate $78 / 96$, red blood cell count $2,87 \times 10^{12} / \mathrm{L}$, hemoglobulin 6,91 $\mathrm{g} / \mathrm{L}$, urinalysis revealing recurrent hemoglobulinuria, the urinary fractional 17-ketosteroids in $24 \mathrm{~h}$ urine 2,6 mg/24 h (normally $16-18 \mathrm{mg} / 24 \mathrm{~h}$ ).

Chest and heart X-ray findings: normal

Pelvis x-ray (2 views): lime salts (calcium apatite)

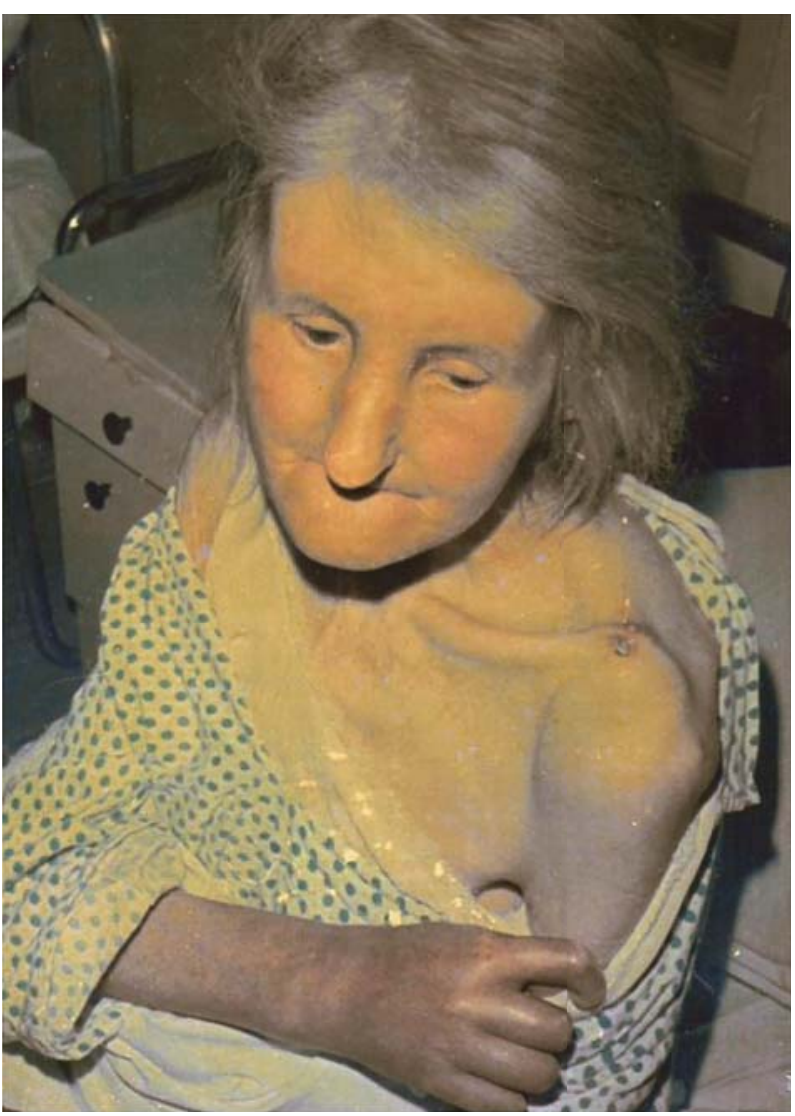

Figure 3. Calcifications are present on the left shoulder with a tendency to secretion

are deposited in the gluteal soft tissues, presenting as grouped oval pinhead- or millet-sized shadows reaching the size of a "green walnut"; lime salts are also observed in other parts of the pelvis (Figure 4). Esophageal peristalsis: the esophagus is normally positioned, dilated, without peristalsis or visible wrinkles, funnel-shaped in the kardia region, with slow flow of barium suspension (Figure 5).

\section{Therapy}

The patient received systemic therapy: antibiotics (penicillin, gentamicin), corticosteroids, progesterone, vasodilators (pentoxifylline), griseofulvin, and multivitamin preparations; corticosteroids and antimycotics were administered topically. Apart from successful management of the secondary infection, some improvement was achieved by progesterone: the skin was softer, finger mobility was slightly better, and the patient subjectively felt better. However, dissolution of calcifications was not achieved by the applied therapy. 


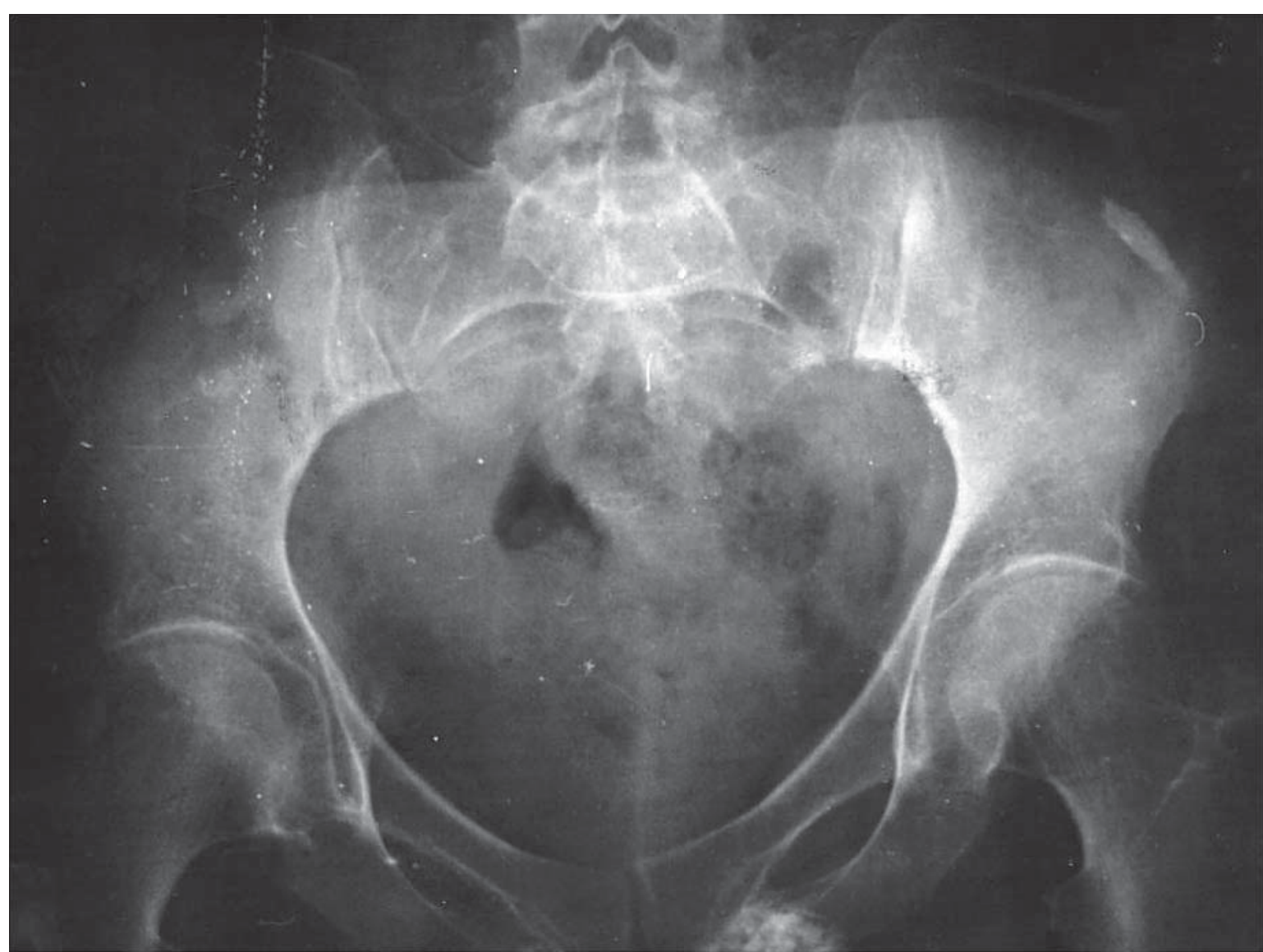

Figure 4. Pelvis $\mathrm{x}$-ray revealing oval pinhead- or millet-sized, grouped shadows in the gluteal soft tissues

\section{Discussion and Literature Review}

Systemic sclerosis (SS) is a rare disease that is more common among women than men, with the peak age of onset between 20 and 50 years (17). The true incidence and prevalence of the disease are unknown, mostly due to a small number of published epidemiological studies, a large variability in the clinical manifestations and severity of the disease, the difficulty in applying classification criteria, and the variability in the design and methods used in epidemiological studies (18). A group of French authors analyzed 32 articles published from 1969 to 2006 in which the prevalence of SSc (systemic sclerosis with sclerosis of the skin) (SSc) ranged from $7 /$ million to $489 /$ million and its incidence from $0.6 / \mathrm{million} / \mathrm{y}$ to $122 / \mathrm{million} / \mathrm{y}$ (18). The prevalence is higher in the US (276 cases per million adults) and Australia (233 cases per million) than in Japan and Europe (France, 158 per million, and England 88 per million). Higher prevalence was established in Afro Americans (315 cases per million) than in Caucasians (224.7 cases per million) (19). According to various studies, the female to male ratio ranges from 1.1: 1 (20) to 14: 1 (21). Earlier onset of the disease is found in women in regard to men (average age for men $58.9 \pm 13.5$ years, and $49.2 \pm 15.7$ years for women (22). SS is rare in children (23).

Systemic scleroderma (SSc) is a SS affecting the skin and a multisystem connective tissue disease of unknown etiology, but it is certainly associated with genetic factors, immune system alterations, and environmental factors $(15,18,24)$. Its pathogenesis involves vascular abnormalities resulting in tissue hypoxia, immune responses manifesting with altered $\mathrm{T}$ - and B-lymphocyte functions and production of autoantibodies, through fibroblast dysfunction and excessive collagen synthesis $(25,26,27)$. A wide variety of hypotheses have been offered to explain the pathogenesis of SSc (25). 


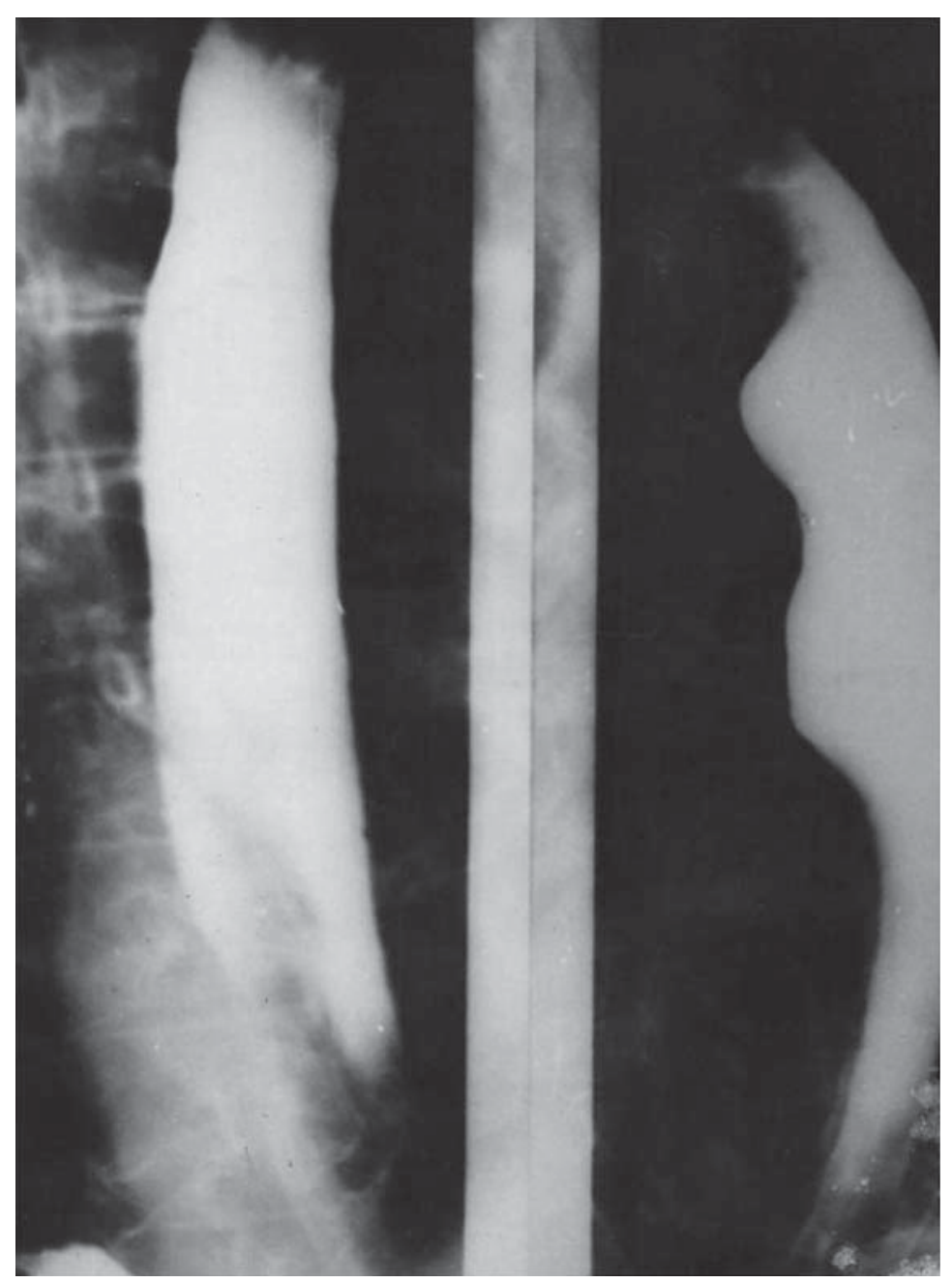

Figure 5. The esophagus is dilated, without peristalsis or visible wrinkles, funnel-shaped in the kardia region

Although familial cases of SSc are rare, a family case history is an important factor in the development of the disease (28). Genetic factors clearly influence disease susceptibility as a complex that includes a number of genes and chromosomal loci (24). The HLA (human leukocyte antigen) genes have been implicated in the susceptibility to SSc (29). Multiple genetic patterns in SSc, and various HLA alleles are associated with different clinical and serological aspects of this disease (30).

The immune hypothesis of SSc patho-genesis emphasizes the role of $\mathrm{T}$ cell-derived cytokines implicated in the damage of the blood vessels and indirectly tissue hypoxia; they also directly stimulate fibroblasts to increased collagen synthesis. $\mathrm{T}$ helper lymphocytes impair humoral immunity and increase in titer of antinuclear antibodies. The immune hypothesis and autoimmune events in the pathogenesis of the SSc is supported by: elevated serum interleukin-2 levels, activated lymphocytes in the biopsy specimens, activated monocytes in the peripheral blood, reduced number of $\mathrm{CD} 8+\mathrm{T}$ lymphocytes, impaired function of NK (natural killer) cells, presence of various autoantibodies and immune complexes (25).

Some environmental factors may play a role in triggering SSc in persons with genetic predisposition, such as physical trauma (long-term exposure to vibration, burns) (11), viral infections (cytomegalovirus, parvovirus B19, herpes virus) or helicobacter pylori, toxic substances (vinyl chloride, some pesticides, benzene derivatives, silica, trichloroethylene, organic solvents, epoxy resins), and drugs (cocaine, appetite suppressants, penicillamine, 
vitamin $\mathrm{K}$, bleomycin, isoniazid) $(11,31,32)$. Relations between systemic sclerosis and occupational exposure to certain chemicals as triggers of systemic scleroderma have been investigated, for example in construction workers and miners who work with explosives, but later studies showed this association to be unreliable (33). There are authors who believe that occupational exposure to organic solvents is not significantly associated with systemic scleroderma, and one should be cautious in interpreting the impact of organic solvents and certain chemicals on the development of scleroderma in textile workers (34). According to the vascular hypothesis of the SS pathogenesis, primary changes affect the blood vessels (intimal thickening and vessel lumen occlusion). Endothelial cells are among the first targets, or primary dysfunctional cells in this disease (35). Precapillar sphincter dilation causes microvascular hypertension, swelling, telangiectasia, and later arteriolar hyperplasia and fibrosis. It is possible that blood vessel insufficiency causes tissue injury, whereas fibrosis is a part of the reparation process. Excessive collagen production results in fibrosis of the skin and internal organs; collagen (types I, III, IV, and VII), fibronectin, glycosaminoglycans, and proteoglycans are deposited in the interstitium and in the intima of small arteries (36). Collagen deposition may be caused by increase in the number of fibroblasts which produce collagen, or increased collagen production in fibroblasts, but also by reduced collagen degradation.

The acronym CREST stands for calcinosis, Raynaud's phenomenon ( $\mathrm{RPh}$ ), esophageal dysmotility, sclerodactyly, telangiectasia syndrome, and dates back to the twentieth century: in 1911, Thibierge and Weissenbach described a patient with skin calcinosis, $\mathrm{RPh}$, sclerodactyly and telangiectasia, and named it CRST syndrome (37). In 1964, Winterbauer registered esophageal dysmotility in 4 of his 8 patients with CRST syndrome (38), and in 1973, Frayha et al. proposed the acronym CREST, due to common occurrence of esophageal dysmotility (39). Later, various combinations of these clinical manifestations have been described, including REST syndrome (without calcinosis), CRest, "Pure" CREST (in patients with two or more symptoms of CREST, but not enough criteria for limited or diffuse systemic sclerosis), "Plus" CREST (association with other forms of systemic scleroderma - limited or diffuse, or with other autoimmune diseases) (40). Our patient was diagnosed with CREST syndrome, fulfilling all criteria. Due to common absence of some manifestations, some authors believe it is more correct to speak about limited cutaneous scleroderma, and that presence of two of five manifestations is sufficient (3), however, this is unlikely to be a separate syndrome distinct from systemic sclerosis, but only a subgroup of systemic sclerosis (41).

Calcinosis is one of the typical manifestations of CREST syndrome, but it may occur in all types of scleroderma. Calcinosis occurs in about $25 \%$ of patients with limited SSc and it can be associated with problems of poor peripheral circulation, causing local skin irritation, inflammation, ulceration and encouraging secondary infection (42). Calcinosis generally results from dystrophic calcification associated with massive collagen degeneration (43). Cutaneous deposition of calcium salts in the skin occurs in a variety of clinical settings, beginning as a calcium phosphate nidus and progressing to hydroxyapatite crystal formation within a collagen matrix (43). Dystrophic calcification is due to accumulation of calcium apatite crystals, with normal levels of serum calcium, phosphorus, and alkaline phosphatase (44). Calcium deposits develop in the skin, as subcutaneous nodules or massive nodes, mainly in the elbows, knees, fingers and toes, but also in other body areas (45). Sometimes they are visible, sometimes just palpable. The overlying skin is thin and often painful. The lumps may break through the skin and leak a chalky white liquid. Secondary infections and inflammations are not uncommon (26). Our patient presented with multiple calcifications of various localization and size, and at one point she needed surgical intervention.

Raynaud's phenomenon (RPh) causes numbness, pain and color changes in fingers in a large number of patients with limited SSc (46). It was first described by Maurice Raynaud in 1862 (47). It is usually the first and often the only symptom of scleroderma for many years, hence its central role in diagnosis of SSc (45). It is usually triggered by exposure to cold or emotional stress; due to spasm of small blood vessels (capillaries) one or more fingers suddenly turn white, become cold and insensitive (48). After a few minutes or longer, lack of oxygen in the blood causes cyanosis and pain in the fingers, but when the circulation gets normal, hyperemia occurs and the skin gets red (49). Between 
episodes the patient is symptom free (26). Secondary $\mathrm{RPh}$ is typical for collagen and vascular diseases; it is usually asymmetric and may be accompanied by ulcerations or necrosis. Primary RPh affects younger individuals, after stressful events or exposure to cold; changes are symmetrical without ulcerations and necrosis (3).

At the age of 43 , our patients presented with $\mathrm{RPh}$ symptoms, initially after exposure to cold, and later regardless of environmental factors; for two years it was the only manifestation of the disease.

Esophageal dysmotility: Although patients with SSc present with changes in the entire gastrointestinal tract, esophageal involvement is most common (26). The majority of patients with CREST syndrome demonstrate hypomotility. The esophageal epithelium may show a cobblestone appearance due to pearly white plaques; apart from subepithelium, fibrosis may also affect regions with muscle atrophy (41). Apart from esophageal aperistalsis, spasms and esophageal stricture have rarely been reported. Esophageal manometry and radionuclide transit test are better than radiography in the detection of motor abnormalities (41).

Esophageal dysmotility is usually found in the lower two-thirds of the esophagus and the lower esophageal sphincter, due to smooth muscle atrophy and fibrosis of the lamina propria and submucosa, atrophy and mucosal erosion and disruption of the capillary network (1). Patients often state they must drink liquids to swallow solid food (50). Esophageal reflux is common (16), as well as nausea, vomiting, weight loss, diarrhea, constipation and bleeding (45, 49). It has been pointed that symptoms of esophageal reflux are twice as common as dysphagia (41).

After five years since the beginning of the disease, our patient presented with difficulties in swallowing, heartburn, and regurgitation with large meals.

Sclerodactyly is the most easily recognizable manifestation, but it is not prominent in all patients (50). It is thickening which generally only involves the skin of the fingers (and toes) distal to the metacarpophalangeal joints in CREST syndrome. Sclerodactyly evolves through three phases: the edematous phase, indurative phase, and atrophic phase (26): the edematous phase begins with finger swelling, morning stiffness, and arthralgias; in the second phase the skin becomes thickened, shiny, without wrinkles, erythematous, and itchy; in the last, atrophic phase, the skin becomes fragile and lax, although it looks thicker due to thight connections with the structures underneath (1). The fingertips are pointed, fixed in an acutely flexed position, with ulcerations and calcifications. The distal phalanges are shortened or missing, hands are stiffened into a claw and immovable (48). The nails are dystrophic, dry, striated, deformed. Skin distal to the elbows and knees, but but also of the neck and face may be involved.

Three years after the appearance of $\mathrm{RPh}$, our patient presented with skin changes on her fingers: first edema, then thickening, thinning, accompanied by reduced mobility and fixed flexion. There were also nail changes. Changes on the face and calcifications were registered 5 years after the onset of the disease.

Telangiectasias may occur in all types of SSc. They affect the face and extremities due to dilation of blood vessels on the skin surface, but also on the mucous membranes (lips, digestive tract) (26). The number and locations of telangiectasias increase over time (50). Our patient had numerous telangiectasias and scars on the shins and dorsum of the feet.

Other symptoms of CREST syndrome include fatigue, weakness, breathing difficulties, dizziness, ulcerations on the fingers and toes, poor wound healing, dry mouth and eyes, problems with the teeth.

Although the majority of patients may be classified into diffuse or limited SSc, there is a possibility of overlapping clinical symptoms, so all patients are at risk for complications of SSc (51).

Pulmonary arterial hypertension is a significant cause of mortality in SSc (52). The prevalence of pulmonary arterial hypertension in diffuse SSc ranges from $4.9 \%$ to $26.7 \%$ (53). However, pulmonary arterial hypertension may be a complication of limited SSc as well $(54,55)$.

Scleroderma renal crisis is a rare but serious complication of SSc (56). It is defined as severe hypertension associated with rapid increase in serum creatinine, with or without microangiopathic hemolytic anemia (57). It occurs in about $20 \%$ of patients with diffuse SSc, but it also affects patients with limited SSc and CREST syndrome (58, 59, 60). Regular renal function monitoring is recommended for all patients with SSc. Corticosteroids, especially high doses, represent a risk for scleroderma renal crisis (61).

Primary biliary cirrhosis (PBC) may also be accompanied by CREST syndrome. The association 
of these two diseases is explained by a common autoimmune mechanism, and it is considered a distinct entity (PBC-CREST). Along with keratoconjunctivitis sicca, it is known as Raynaud's syndrome. According to Tojo and associates (62), patients with PBC-CREST have milder symptoms than patients with PBC or CREST alone, but have a larger number of esophageal varices. High titers of anti-centromere antibodies (ACA), low titers of antimitochondrial antibodies, high prevalence of HLADR9 and better prognosis are registered in patients with PBC-CREST. This association is well known in women, but it may also occur in men (63).

Using non-invasive cardiovascular magnetic resonance (CMR) imaging (64), coronary artery abnormalities and myocardial fibrosis can be registered, and all patents with SSc present with multiple fibrotic areas (65). The pathogenesis of the fibrotic lesions in SSc is still unclear. However, a spasm of small coronary arteries (myocardial Raynaud's phenomenon) has been suggested as a possible mechanism (65). Mavrogeni et al. (66), used CMR to evaluate 5 patients with CREST syndrome and 5 patients with SSc. All patients with CREST syndrome presented with coronary artery ectasia, whereas patients with SSc were without cardiac symptoms with normal coronary artery findings, but patchy fibrosis was identified in all of them (66)..

Anemia has also been associated with CREST syndrome (67) as a result of jejunal telangiectasias, with normal colposcopic findings and esophagitis.

Lauritano et al. (68) observed tongue rigidity and some speckled red alternating with white spots on the hard palate and in the vestibule in patients with Sjögren's syndrome and CREST.

CREST syndrome is rarely associated with other malignancies (69). It has been suggested that patients with scleroderma and Barrett's metaplasia are at increased risk of complications, such as strictures or adenocarcinoma, cases of CREST syndrome and lung adenocarcinoma, esophageal carcinoma, and adenocarcinoma of the third portion of the duodenum $(41,69)$.

Hachulla and Launay (70) reviewed the literature concerning the diagnosis and classification of SSc, describing characteristics of certain forms of the disease. In diffuse cutaneous form of SSc, disease progression is very fast, with a high incidence of renal, cardiac and pulmonary alterations (71).
These characteristics also include: $\mathrm{RPh}$ episodes with fast skin changes, changes on the trunk and acral parts of the body, presence of tendon friction rubs, early and significant appearance of interstitial lung disease, chronic renal failure with oliguria, diffuse gastrointestinal diseases, with involvement of myocardium, genitourinary and musculoskeletal system, absence of ACA, dilatation of capillaries and nailfold capillary destruction, autoantibodies against Topoisomerase I (Scl 70) (in 30\% of patients) (10, 16). The limited cutaneous SSc is characterized by slow progression, and less frequent and later spread on the internal organs. $\mathrm{RPh}$ is recorded in the course of several years, skin sclerosis affects the hands, face, legs and forearms (acral parts); there is a significantly lower incidence of pulmonary hypertension, with or without interstitial lung disease, trigeminal neuralgia, calcification and skin telangiectasia, often with ACA (anticentromere antibody that reacts with the kinetocore of metaphase chromosomes) in $40-70 \%$ (41), dilated nailfold capillaries (10).

Systemic sclerosis sine scleroderma (ssSSc) is a rare disorder in which patients develop vascular and fibrotic damage to internal organs, in the absence of cutaneous sclerosis (72). Brazilian authors studied 947 consecutive patients with SSc and 8.3\% were classified as ssSSc (73). In this series, patients with ssSSc had a relatively mild type of disease with good prognosis. The disease was characterized by (13): $\mathrm{RPh}$ with a peripheral vascular equivalent (digital pitting scars, digital tip ulcers, digital tip gangrene and abnormal nailfold capillaries), positive antinuclear antibodies (ANA), one visceral organ involvement typical of SSc (any one of the following: distal esophageal hypomotility, small bowel hypomotility, pulmonary interstitial fibrosis, pulmonary hypertension, cardiac involvement typical of scleroderma or renal failure consistent with scleroderma renal crisis) and absence of another defined connective tissue or other disease as a cause of signs and symptoms cited above.

Scleroderma overlap syndromes mostly include simultaneous occurrence of sclerosis and some autoimmune systemic diseases (polymyositis, systemic lupus erythematosus or rheumatoid arthritis). If only $\mathrm{RPh}$, ulcers, digital pitting ulcers, and ANA are present, with no other signs of systemic disease, it is presystemic scleroderma (1), corresponding with prodromal cutaneous sclerosis syndrome. 
Rare cases of nodular and keloidal scleroderma have also been described. There are two categories: 1) systemic scleroderma accompanied by generalized distribution of ivory-colored subcutaneous nodules 3-20 $\mathrm{mm}$ in diameter, whose histology shows fibromatous changes or fibrinoid necrosis, and 2) localized scleroderma, subcutaneous morphea/ deep morphea/morphea profundus, with localized or generalized nodules; the skin is pigmented or hypopigmented, while most morphea nodules are said to be non-progressive (41). Localized scleroderma is characterized by extensive deposition of collagen with a thickening of the dermis and/or subcutaneous tissue. Unlike systemic sclerosis, it presents without sclerodactyly, $\mathrm{RPh}$, nail changes, telangiectasia and progressive involvement of internal organs (41).

Speaking of patients with SSc, the most common subsets are limited cutaneous (approximately 60\% of patients with systemic sclerosis) and diffuse cutaneous (approximately 35\% of patients with systemic sclerosis), whereas systemic sclerosis without scleroderma affects about 5\% (16). Approximately $15 \%$ of patients have pulmonary hypertension, and $10 \%$ have overlap syndromes.

The diagnosis of systemic sclerosis is based on the following $(11,41)$ :

A. Clinical findings: 1) Medical history (on the overall health status, development of the disease and symptoms, exposure to possible precipitating factors, symptoms involving the lungs, heart, gastrointestinal tract, kidneys, muscles, etc.). 2) Clinical examination of the skin and other organs, and diagnostic criteria;

B. Diagnostic tests: Erythrocyte sedimentation rate, blood count, biochemical analyses; Skin biopsy; $\mathrm{X}$-ray of the lungs, heart and esophagus; CT scan o the bones (in patients with calcinosis CT should be done when radiography findings are normal); Esophageal manometry and radionuclide transit are better than radiography for showing motor abnormalities; plethysmography, laser Doppler flowmetry, thermography, finger systolic blood pressure are used in the $\mathrm{RPh}$ (26); Cardiovascular magnetic resonance imaging is used to detect changes in the coronary arteries and the heart muscle, but major differences between limited and diffuse SSc are not probable (74).

The diagnosis of $\mathrm{RPh}$ is made using: plethysmography, laser Doppler flowmetry, thermography, finger systolic blood pressure (26). Serological tests: antinuclear antibodies (ANA) (90\% - 95\% in limited cutaneous and diffuse cutaneous SSc) (75). Other tests are used depending on the affected organ: pulmonary function tests, chest radiography, electrocardiogram, gastrointestinal motility testing, renal function tests, etc.

C. Diagnostic criteria of the American College of Rheumatology (ACR) (9). The patient should fulfill a major criterion or two of the three minor criteria:

I Major criteria - Scleroderma proximal to the digits, affecting limbs, face, neck or trunk - this is a single major criterion.

II Minor criteria;

(a) sclerodactyly

(b) digital pitted scarring

(c) bilateral basal pulmonary fibrosis.

Nadashkevich et al. (76) have proposed nine criteria - ABCDCREST: A. autoantibodies to: centromere proteins, Scl-70 (TOPO I), or antifibrillarin; B. bibasilar pulmonary fibrosis; C. contractures of the digital joints or prayer sign; 4. D. dermal thickening proximal to the wrists; 5 . C. skin calcinosis; 6. RPh - Raynaud's phenomenon; 7. E. - esophageal distal hypomotility or reflux-esophagitis; 8. S. - sclerodactyly or non-pitting digital edema; 9. T. - telangiectasias. The classification of definite SSc requires at least three of the above criteria. Although presence of topoisomerase 1 (Scl-70) is extremely rare in localized scleroderma, autoantibodies to topoisomerase 11 were found in $70 \%$ of patients with localized scleroderma, and $85 \%$ of patients with generalized morphea (41).

Classification criteria for systemic sclerosis, published by the American College of Rheumatology/ European League Against Rheumatism Collaborative Initiative (77) in 2013, include 8 criteria validated by a number of points, so that the definite diagnosis of SSc is set if the total score is 9 or more. These are: 1) skin thickening of fingers of both hands extending proximally to the metacarpophalangeal joints (sufficient criterion - 9 points); 2) finger tip lesions, edema - 2 points, sclerodactyly - 4 points; 3) finger lesions, ulcerations - 2 points; finger tippitting scars - 3 points; 4) telangiectasias - 2 points; 5) abnormal nailfold capillaries - 2 points; 6) lung involvement, pulmonary arterial hypertension - 2 points; interstitial lung disease - 2 points; 7) $\mathrm{RPh}-3$ points; 8 ) scleroderma related antibodies -3 points. 
In recent years a number of authors $(78-82)$ is working on the revision of the classification criteria, including a broad range of clinical and laboratory elements that characterize SSc, which should contribute more accurate diagnosis, therapy and prevention of complications of the disease. Nailfold capillary microscopy (NCM) is a method used to assess the degree of capillary dilation (83), being very important for early diagnosis of SSc. NCM has significantly improved the identification of clinical differences (84), and that is why diagnostic sensitivity of ACR criteria may be markedly improved by addition of simple clinical variables, including NCM abnormalities and ACA positivity, as novel minor criteria (83). Capillary patterns may correlate with visceral involvement and capillaroscopy thus has the potential as a screening tool to enable early diagnosis of organ involvement in systemic sclerosis, as well as early therapy and prevention of disease progression (85). This method allows: early diagnosis of systemic sclerosis without skin involvement, differentiation of primary $\mathrm{RPh}$ from secondary $\mathrm{RPh}$ and follow up of disease progression (86). Today, videocapillaroscopy is most widely used (87). When comparing NCM and dermoscopy, most nailfold capillary images can be classified and assessed with higher accuracy (88).

Serological tests are of great importance in the diagnosis and differential diagnosis, especially related to the presence of antinuclear antibodies (ANA), which are the expression of autoimmune response (35), and clinically are associated with pulmonary and arterial hypertension, and interstitial lung disease; ANA may be present in healthy individuals as well, but in low percentage (89). Anticentromere antibodies (ACA) are found in 40 to $70 \%$ of patients with limited cutaneous sclerosis and are associated with calcinosis, RPh, esophageal dysmotility, sclerodactyly, telangiectasia, and pulmonary arterial hypertension; they are found only in 2 to $5 \%$ of patients with diffuse scleroderma, when they are associated with digital ulceration or digital loss. ACA findings indicate capillary involvement (90). Anti-topoisomerase I (anti-Scl-70) autoantibodies are found in 20 to $40 \%$ of patients with diffuse cutaneous sclerosis, and only $6 \%$ with limited cutaneous SSc; they are associated with rapid progression of skin thickening, scleroderma, renal crisis, pulmonary fibrosis, joint, muscle and heart involvement, hypertension and proteinuria (91). Anti-fibrillin-1 antibodies (U1RNP) indicate a serious involvement of skin and systemic organs with high mortality, whereas antinucleolar antibodies indicate a limited form of the disease; however, they can be detected in patients with pulmonary hypertension and pulmonary fibrosis (75). Anti-RNA Polymerase III (Pol 3) antibodies are registered in $10-20 \%$ of patients with SSc, pointing to a serious disease with scleroderma, renal crisis and association with malignancy (91).

There is a registered association between SSc and various HLA alleles (92). Scleroderma is associated with HLA-DQA1* 0501 and DQB1* 0301 allele in all ethnic groups, DRB1* 1104 in Caucasians and Hispanics, and DRB1* 0804 in African Americans (93). HLA-DRB1 alleles are associated with limited scleroderma (29), and $\mathrm{B}^{*} 62, \mathrm{DRB} 1^{*}$ 11 and DRB1* 07 with diffuse scleroderma $(1,94)$. Pulmonary fibrosis is associated with HLAB* 62 and HLA $\mathrm{Cw}^{*} 0602$, and pulmonary hypertension with HLAB* $^{*} 13$ and HLAB* 65 (29). There is a correlation between the connective-tissue growth factor (CTGF), and systemic sclerosis, particularly in patients with anti-Scl-70 antibodies and pulmonary fibrosis (95). The presence of certain HLA alleles correlates with the presence of autoantibodies specific for systemic scleroderma $(93,96)$.

Differential diagnosis includes $(16,41): \mathrm{RPh}$ of occupational origin, vibration-induced injuries, other connective tissue diseases or mixed connective tissue diseases (eg, rheumatoid arthritis or systemic lupus erythematosus), undifferentiated connective tissue disease, amyloidosis, paraneoplastic syndrome, and pseudoscleroderma (congenital, metabolic, toxic, chronic graft-versus-host disease).

Despite numerous new findings, there is still no therapeutic algorithm that can significantly change the natural course of the disease. Symptomatic treatment is of great importance (35).

The therapy of SSc depends on the segment in the pathogenesis of the disease which is being treated, e.g. changes in the vascular system, increased collagen synthesis, or modified immune reactivity (1). Vasoactive treatment includes: prostacyclin, low molecular weight dextran, stanozolol, nifedipine, captopril, ketanserin and plasmapheresis. Collagen production is affected by: D-penicillamine, pentoxifylline, coagulation factor XIII, cyclofenil, 
colchicine, griseofulvin, 13-cis retinoic acid. Immune therapy includes: prednisone, cyclophosphamide, azathioprine, cyclosporine.

Hinchcliff and Varga (16) presented a treatment overview of organ specific complications of SSc (16):

Raynaud's phenomenon - $\alpha$-Adrenergic blockers, angiotensin-II receptor blockers, long-acting calcium channel blockers (dihydropyridines), pentoxifylline (Trental), stellate ganglionic blockades, digital sympathectomy;

skin fibrosis - immunomodulatory drugs (d-penicillamine, mycophenolate mofetil, cyclophosphamide;

gastroesophageal reflux - antacids, histamine $\mathrm{H} 2$ blockers, proton pump inhibitors;

intestinal dysmotility or bacterial overgrowth - antibiotics, correction of nutritional deficiencies, promotility agents;

pulmonary fibrosis or alveolitis - immunomodulatory drugs, initial therapy with oral or intravenous cyclophosphamide, maintenance therapy with azathioprine;

pulmonary arterial hypertension - diuretics, endothelin-1 receptor inhibitors (bosentan), oxygen, phosphodiesterase- 5 inhibitors (sildenafil), prostacyclin analogues (epoprostenol, treprostinil, iloprost), warfarin (sometimes used in patients with recurrent pulmonary thromboembolic disease);

scleroderma renal crisis - dialysis, short-acting angiotensin-converting enzyme inhibitors.

Manno and Boin (97) gave an overview of immunomodulators which are used in the therapy of SSc including: category, name of the drug, mechanism of action, and recommended doses:

1. nonselective immunosuppressive therapy: cyclophosphamide, mycophenolate mofetil, azathioprine, methotrexate;

2. T-cell-targeted immunotherapy: cyclosporine A, antithymocyte globulin, extracorporeal photoimmunotherapy or photopheresis, sirolimus (rapamycin);

3. B-cell-targeted immunotherapy: rituximab;

4. intravenous immunoglobulins;

5. biological immunotherapy: anti-TNF- $\alpha$ agents, infliximab;

6. antifibrotic therapy: CAT-192, imatinib mesylate;

7. cell-based immunotherapy: autologous hematopoietic stem cell transplantation.
In some cases, clinical improvement in patients with SSc is obtained by UVA-1 phototherapy (98).

Meta-analysis was conducted to determine the efficacy of calcium channel blockers for RPh, pointing to a moderate reduction in the frequency and severity of ischemic attacks (99). The following blockers were evaluated: nifedipine, nicardipine, nisoldipine, diltiazem; nifedipine was indicated for $\mathrm{RPh}$, since it significantly reduced the frequency and severity of ischemic attacks with highest therapeutic efficacy (100). Type V phosphodiesterase inhibitor, sildenafil, stimulates accumulation of cyclic guanosine monophosphate, decreasing intracellular calcium concentrations, inducing relaxation of the vascular smooth muscle and consequent dilation $(101,102)$. Several-week use of sildenafil causes significant reduction in the frequency and severity of RPh (102). A synthetic phosphodiesterase III inhibitor, cilostazol increases conduit vessel diameter in patients with primary and secondary $\mathrm{RPh}$, with a favorable impact on conduit vessel responsiveness to cold in patients with primary $\mathrm{RPh}$ without affecting microvascular flow or symptoms (103). Selective alpha-adrenergic receptor blocker acts in the recovery from coldinduced vasospasm in scleroderma patients (104). If topical glyceryl trinitrate is used in the treatment of primary RPh or limited SSc, it may cause endotheliumdependent vasodilator effect (105).

The mechanism of calcinosis formation is not entirely understood, and no effective treatment is available (106). However, low doses of warfarin may be effective in some patients with early and moderate SSc. Minocycline may be effective in the control of calcinosis in systemic sclerosis. The mechanism of action may be mainly through inhibition of matrix metalloproteinases and anti-inflammatory effects (42). Physical therapy of calcinosis includes: extracorporeal shock wave lithotripsy (107), carbon dioxide laser (108), and erbium laser (109). Treatment of finger calcinosis has a wide range of possibilities depending on the extent of calcifications and the involvement of deep structures. From a surgical point of view, simple removal is adequate in minor outpatient cases, whereas radical debridement is required in the major and more painful cases (44). Laser surgery may reduce telangiectasias, and amputation is sometimes necessary in gangrene.

Topical therapy includes (11): 
- broad-spectrum topical antibiotics;

- nitroglycerin ointment for ischemic ulcers;

- topical antipruritics;

- emollients.

Other forms of therapy $(31,32)$ :

- patient education on the characteristics of the disease and awareness of urgent problems;

- physiotherapy to promote joint mobility and muscle strength;

- exercises to maintain range of motion (mouth, face and hand stretches);

- avoid tobacco and maintain healthy weight;

- nutritional advice, and supplements if needed;

- for Raynaud's phenomenon: avoid cold and trauma, use warm clothing or heated clothing; For an attack - warm the body, hands and feet, use gentle arm movements or gentle massage to help restore circulation;

- occupational therapists - for adaptations to assist in daily living;

- camouflage products - cosmetics.

Skin protection: Avoid harsh soaps and detergents; reduce bathing frequency (bathe just once a day or every other day, using warm rather than hot water); apply sunscreen and increase moisture levels in your home by using a humidifier;

- practice good oral hygiene.

The prognosis and course of the disease indicate that although spontaneous remission is possible, SSc is essentially a chronic disease with progressive course with possible crises due to organ involvement. The patient should be informed about the objective circumstances in terms of clinical manifestations and treatment options, with high commitment of the entire team of doctors and psychotherapy.

\section{Conclusion}

When classifying systemic scleroderma into two groups - diffuse and limited, with CREST syndrome as a variant of the latter, it should be considered that both types represent clinical variants of systemic sclerosis, share similar visceral involvement, laboratory abnormalities and the course which is not invariable, as shown in our patient. We reported a case of a patient with typical features of limited SSc, and all the symptoms of CREST syndrome, in whom the disease lasted for 23 years; therapeutic modalities provided only temporary improvement, eventually resulting in a fatal outcome.

\section{Abbreviations}

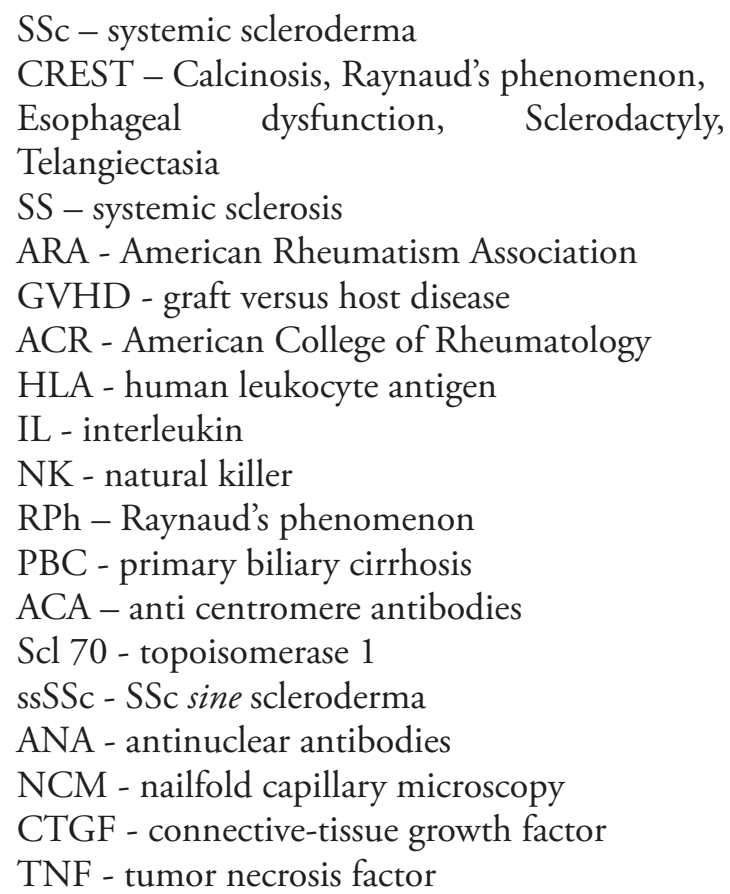

\section{References}

1. Karadaglić Đ, Pavlović M. Sklerodermija. In: Karadaglć Đ, editor. Dermatologija. Beograd: Vojnoizdavački zavod, Versalpress Beograd; 2000. p. 1721-41.

2. Jimenez SA, Derk CT. Following the molecular pathways toward an understanding of the pathogenesis of systemic sclerosis. Ann Intern Med 2004; 140: 37-50.

3. Fabri M, Hunzelmann N. Differential diagnosis of scleroderma and pseudoscleroderma. J Dtsch Dermatol Ges 2007;5(11):977-84.

4. Mavrogeni S, Bratis C, Manoussakis M. Coronary artery abnormalities in CREST syndrome revealed by cardiovascular magnetic resonance imaging. Can J Cardiol 2011;27:390e5-7.

5. Tuffanelli DL, Winkelman RK. Diffuse systemic scleroderma. A comparison with acrosclerosis. Ann Intern Med 1962;57:198-203.

6. Barnnett AJ. Scleroderma (progressive systemic sclerosis): progress and course based on a personal series of 118 cases. Med J Aust 1978;2:129-34.

7. Rodnan GP, Jablonska S, Medsger TA. Classification and nomenclature of progressive systemic sclerosis (scleroderma). Clin Rheum Dis 1979;5:5-13.

8. Giordano M, Valentini G, Migliaresi S, Picillo U, Vatti M. Different antibody patterns and different prognoses in patient with scleroderma with various extent of skin sclerosis. J Rheumatol 1986;13:911-6.

9. LeRoy EC, Black C, Fleischmajer R, Jablonska S, Krieg T, Medsger TA, et al. Scleroderma (systemic sclerosis): classification, subsets and pathogenesis. J Rheumatol 1988;15:202-5.

10. Subcommittee for Scleroderma Criteria of the American Rheumatism Association Diagnostic and Therapeutic Criteria Committee. Arthritis Rheum 1980;23:581-90. 
11. Drake LA, Dinehart SM, Farmer ER, Goltz RW, Graham GF, Hordinsky MK, et al. Guidelines of care for scleroderma and sclerodermoid disorders. J Am Acad Dermatol 1996;35:609-14.

12. LeRoy EC, Medsger TA. Criteria for the classification of early systemic sclerosis. J Rheumtol 2001;28:1573-6.

13. Poormoghim H, Lucas M, Fertig N, Medsger TA, Jr. Systemic sclerosis sine scleroderma: demographic, clinical and serologic features and survival in forty-eight patients. Arthritis Rheum 2000;43:444-51.

14. Maricq HR, Valter I. A working classification of scleroderma spectrum disorders: a proposal and the results of testing on a sample of patients. Clin Exp Rheumatol 2004;22(3 Suppl. 33):S5-13.

15. Walker JG, Pope J, Baron M, LeClercq S, Hudson M, Taillefer $S$, et al. The development of systemic sclerosis classification criteria. Clin Rheumatol 2007;26:1401-9.

16. Hinchcliff M, Varga J. Systemic sclerosis/scleroderma: a treatable multisystem disease. Am Fam Psysican 2008;78(8):9618.

17. Habif TP, Campbell JL, Chapman MS, Dinulos JGH, Zug KA. Skin disease diagnosis and treatment. Philadelphia: Elsevier Mosby; 2005. p. 354-7.

18. Chifflot H, Fautrel B, Sordet C, Chatelus E, Sibilia J. Incidence and prevalence of systemic sclerosis: a systematic literature review. Semin Arthritis Rheum 2008;37:223-35.

19. Mayes MD, Lacey JV Jr, Beebe-Dimmer J, Gillespie BW, Cooper B, Laining TJ, et al. Prevalence, incidence, survival, and disease characteristics of systemic sclerosis in a large US population. Arthritis Rheum 2003; 48:2246-55.

20. Englert H, Joyner J, Bade R, Thompson M, Morris D, Chambers P, et al. Systemic scleroderma: a spatiotemporal clustering. Int Med J 2005;35:228-33.

21. Tamaki T, Mori S, Takehara K. Epidemiological study of patients with systemic sclerosis in Tokyo. Arch Dermatol Res 1991;283:366-71.

22. Alamanos Y, Tsifetaki N, Voulgari PV. Epidemiology of systemic sclerosis in Northwest Greece 1981 to 2002. Semin Arthritis Rheum 2005;34:714-20

23. Scalapino K, Arkachaisri T, Lucas M, Fertig N, Helfrich DJ, Londino AV Jr, et al. Childhood onset systemic sclerosis: classification, clinical and serologic features, and survival in comparison with adult onset disease. J Reumatol 2006;33(5):1004-13.

24. Tan FK. Systemic sclerosis: the susceptible host (genetics and environment). Rheum Dis Clin North Am 2003;29:211-37.

25. Radić M, Martinović Kaliterna D, Fabijanić D, Radić J. Sistemska skleroza- patogeneza, kliničke manifestacije i liječenje. Liječ Vjesn 2010;132:162-8.

26. Yoon JC, Elston DM. CREST syndrome treatment and management. Medscape Drug, Disease and Procedures. [updated 2015 Oct 15; cited 2015 Oct 23]. Available from: http:// emedicine.medscape.com/article/1064663-treatment

27. Wollheim FA. Classification of systemic sclerosis. Visions and reality. Rheumatology 2005;44:1212-6.

28. Herrik AL, Worthington A. Genetic epidemiology: systemic sclerosis. Arthritis Res 2002;4:165-8.

29. Gladman DD, Kung TN, Siannis F, Pellett F, Farewell VT, Lee P. HLA markers for susceptibility and expression in scleroderma. J Rheumatol 2005;32(8):1481-7.

30. Del Rio APT, Sachetto Z, Sampaio-Barros PD, MarquesNeto JF, Santos Londe AC, Barros Bertolo M. HLA markers for poor prognosis in systemic sclerosis Brazilian patients. Dis Markers 2013;35(2):73-8.

31. Hartree N, Harding M, Jackson C. Systemic sclerosis (scleroderma). [cited 2015 Oct 1]. Available from: http://patient. info/doctor/systemic-sclerosis-scleroderma

32. Limited scleroderma (CREST syndrome). ). [cited 2015 Oct 1]. Available from: http://www.mayoclinic.org/diseases-conditions/crestsyndrome/basics/definition/con-20031524

33. Maitre A, Hours M, Bonneterre V, Arnaud J, Arslan MT, Carpentier P, et al. Systemic sclerosis and occupational risk factors: role of solvents and cleaning products. J Rheumatol 2004;31(12):2395-401.

34. Bovenzi M, Barbone F, Pisa FE, Betta A, Romeo L, Tonello A, et al. A case-control study of occupational exposures and systemic sclerosis. Int Arch Occup Environ Health 2004;77:10-6.

35. Goodfield MJD, Jones SK, Veale DJ. The connective tissue diseases. In: Burns T, Breathnach S, Cox N, Griffiths C, editors. Rook's Textbook of Dermatology. $8^{\text {th }}$ ed. London: Wiley-Blackwell; 2010. p. 51.64-51.79.

36. Postiglione L, Montagnani S, Riccio A, Montuori N, Sciorio $S$, Ladogana P, et al. Enhanced expression of the receptor for granulocyte macrophage colony stimulating factor on dermal fibroblasts from scleroderma patients. J Rheumatol 2002;29(1):94-101.

37. Thibierge G, Weissenbach R. Concretions calcaires souscutanées et sclerodermie. Ann Dermatol Syph 1911;4:129-55.

38. Winterbauer RH. Multiple telangiectasia, Raynaud`s phenomenon, sclerodactyly, and subcutanious calcinosis: a syndrome mimicking hereditary hemorrhagic telangiectasia. Bull Johns Hopkins Hosp 1964;114:361-83.

39. Frayha RA, Scarola JA, Hulman LE. Calcinosis in scleroderma: a reevaluation of the CREST syndrome (abstract). Arthritis Rheum 1973;16:542.

40. Ensz S. Kidney (renal) involvement (main meni). International Scleroderma Network; c1998-2015 [cited 2015 Oct 1]. Available from: http://www.sclero.org/scleroderma/ symptoms/renal/a-to-z.html

41. Goodfield MJ, Jones SK, Veale DJ. The connective tissue diseases. In: Burns T, Breathnach S, Cox N, Griffiths C, editors. Rook's textbook of dermatology. $8^{\text {th }}$ ed. Oxford: Blackwell Publishing; 2010. p. 51.1-51.138.

42. Robertson LP, Marshall RW, Hickling P. Treatment of cutaneous calcinosis in limited systemic sclerosis with minocycline. Ann Rheum Dis Mar 2003;62(3):267-9.

43. Kawakami T, Soma Y, Mizoguchi M, Saito R. Immunohistochemical analysis of transforming growth factor-beta 3 in calcinosis in a patient with systemic sclerosis and CREST syndrome. Br J Dermatol 2000;143:1097-131.

44. Merlino G, Germano S, Carlucci S. Surgical management of digital calcinosis in CREST syndrome. Aesthetic Plast Surg 2013;37:1214-9.

45. Ngan V. Systemic sclerosis. Derm Net NZ c2003. [updated 2014 Dec 25; cited 2015 Oct 1]. Available from: http://www. dermnetnz.org/immune/systemic-sclerosis.html.

46. Limited scleroderma (CREST syndrome). [cited 2015 Oct 1]. Available from: http://www.medicalgeek.com/diseasesyndromes-procedures/15910-limited-scleroderma-crestsyndrome.html.

47. Raynaud M. De l’asphyxie local de la gangrene symetrique des extremites. Paris: L. Leclerc; 1862.

48. Paravina M. Bolesti vezivnog tkiva. In: Paravina M, Spalević 
Lj, Stanojević M. Tiodorović J, Binić I, Jovanović D. Dermatovenerologija. Niš: Prosveta; 2006. p. 219-28.

49. Limited scleroderma (CREST syndrome). [cited 2015 Oct 1]. Available from: www.drugs.com/mcd/limited-sclerodermacrest-syndrome

50. CREST Syndrome. [cited 2015 Oct 1]. Available from: http://en.wikipedia.org/ wiki/CREST-syndrome

51. Hachulla E, Coghlan JG. A new era in the management of pulmonary arterial hypertension related to scleroderma: endothelin receptor antagonism. Ann Rheum Dis 2004;63:1009-14.

52. Proudman SM, Stevens WM, Sahhar J, Celermajer D. Pulmonary arterial hypertension in systemic sclerosis: the need for early detection and treatment. Intern Med J 2007;37:485-94.

53. Wigley FM, Lima JA, Mayes M, McLain D, Chapin JL, Ward-Able C. The prevalence of undiagnosed pulmonary arterial hypertension in subjects with connective tissue disease at the secondary health care level of community- based rheumatologists (the UNCOVER study). Arthritis Rheum 2005;52:2125-32.

54. Chang B, Schachna L, White B, Wigley FM, Wise RA. Natural history of mild-moderate pulmonary hypertension and the risk factors for severe pulmonary hypertension in scleroderma. J Rheumatol 2006;33: 269-74.

55. Cox SR, Walker JG, Coleman M, Rischmueller M, Proudman $\mathrm{S}$, Smith $\mathrm{MD}$, et al. Isolated pulmonary hypertension in scleroderma. Inter Med J 2005;35:28-33.

56. Batal I, Domsic RT, Medsger TA, Bastacky S. Scleroderma renal crisis: a pathology perspective. Int $\mathrm{J}$ Rheumatol 2010;2010:543704.

57. Steen VD, Medsger TA Jr. Long-term outcomes of scleroderma renal crisis. Ann Intern Med 2000;133:600-3.

58. Tarcin O, Tarcin O, Ozcivan M, Aydin H, Tiftikci A. CREST syndrome and Renal involvement. Marmara Med J 2007;20(3):186-9.

59. Sugimoto T, Sanada M, Kashiwagi A. Is scleroderma renal crisis with anti-centromere antibody-positive limited cutaneous systemic sclerosis overlooked in patients with hypertension and or renal dysfunction? Nephrology 2008;13(2): 179-80.

60. Sugimoto T, Soumura M, Soumura M. Scleroderma renal crisis in a patient with anticentromere antibody-positive limited cutaneous systemic sclerosis. Mod Rheumatol 2006;16(5):309-11.

61. Trang G, Steele R, Baron M, Hudson M. Corticosteroids and the risk of scleroderma renal crisis: a systematic review. Rheumatol Int 2012;32(3):645-53.

62. Tojo J, Ohira H, Suzuki T, Takeda I, Shoji I, Kojima T, et al. Clinicolaboratory characteristics of patients with primary biliary cirrhosis associated with CREST symptoms. Hepathol Res 2002;22:187-95.

63. Kouraklis G, Glinavou A, Karatzas G. Primary biliary cirrhosis accompanied by CREST syndrome. South Med J 2002;95(9):1058-9.

64. Mavrogeni S, Manoussakis MN, Karagiorga TS, Douskou M, Panagiotakos D, Bournia V, et al. Detection of coronary artery lesions and myocardial necrosis by magnetic resonance in systemic necrotizing vasculitides. Arthitis Rheum 2009;61:1121-9.

65. Mavrogeni S, Bratis C, Manoussakis M. Coronary artery abnormalities in crest syndrome revealed by cardiovascular magnetic resonance imaging. Can J Cardiol 2011; 27:390e5-7.
66. Tzelepis GE, Kelekis NL, Plastiras SC, Mitseas P, Economopoulos N, Campolis C, et al. Pattern and distribution of myocardial fibrosis in systemic sclerosis: a delayed-enhanced magnetic resonance imaging study. Arthritis Rheum 2007;56:3827-36.

67. Lachter J, Suissa A, Schiff E, Rosner I. Anemia in CREST syndrome. Isr Med Assoc J 2003:5:449.

68. Lauritano D, Bussolati A, Baldoni M, Leonida A. Scleroderma and CREST syndrome: a case report in dentistry. Minerva Stomatol 2011;60(9):443-65.

69. Anastasopoulos G, Marinis A, Konstantinidis C, Theodosopoulos T, Fragulidis G, Vassiliou I. Adenocarcinoma of the third portion of the duodenum in a man with CREST syndrome. World J Surg Oncol 2008;6:106.

70. Hachulla E, Launay D. Diagnosis and classification of systemic sclerosis. Clin Rev Allergy Immunol 2011;40:78-83.

71. Haustein UF. Scleroderma and pseudo-scleroderma: uncommon presentations. Clin Dermatol 2005;23:480-90.

72. Mayes MD, Ho KT. Understanding and managing scleroderma. Scleroderma foundation. [cited 2015 Oct 1]. Available from: http://www.scleroderma.org/site/DocServer/UandM. pdf?docID $=326$

73. Marangoni RG, Rocha LF, Del Rio AP, Yoshinari NH, Marquez-Neto JF, Sampaio-Barros PD. Systemic sclerosis sine scleroderma: distinct features in a large Brazilian cohort. Rheumatology 2013;52:1520-4.

74. Hachulla AL, Launay D, Gaxotte V, de Groote P, Lamblin N, Devos $\mathrm{P}$, et al. Cardiac magnetic resonance imaging in systemic sclerosis: a cross-sectional observational study of 52 patients. Ann Rheum Dis 2009:68:1878-84.

75. Lyons R, Narain S, Nichols C, Satoh M, Reeves WH. Effective use of autoantibody tests in the diagnosis of systemic autoimmune disease. Ann N Y Acad Sci 2005;1050:217-28.

76. Nadashkevich O, Davis P, Fritzler MJ. A proposal of criteria for the classification of systemic sclerosis. Med Sci Monit 2004;10(11):CR615-21.

77. Van den Hoogen F, Khanna D, Fransen J, Johnson SR, Baron M, Tyndall A, et al. 2013 Classification criteria for systemic sclerosis: an American college of rheumatology / European league against rheumatism collaborative initiative. Artritis Rheumat 2013;65(11):2737-47.

78. Fransen J, Johnson SR, van den Hoogen F, Baron M, Allanore Y, Carreira PE, et al. Items for developing Revised Classification Criteria in systemic sclerosis: results of a consensus exercise. Arthritis Care Res (Hoboken) 2012;64(3):351-7.

79. Johnson SR, Fransen J, Khanna D, Baron M, van den Hogen F, Medsger TA Jr, et al. Validation of potential classification criteria for systemic sclerosis. Arthritis Care Res (Hoboken) 2012;64(3):358-67.

80. Minier T, Guiducci S, Bellando-Randone S, Bruni C, Lepri G, Czirjak L, et al. Preliminary analysis of the very early diagnosis of systemic sclerosis (VEDOSS) EUSTAR multicentre study: evidence for puffy fingers as a pivotal sign suspicion of systemic sclerosis Ann Rheum Dis 2014;73(12):2087-93.

81. Muller-Ladner U, Tyndall A, Czirjak L, Denton C, MatucciCerinic M, EUSTAR centres. Ten years EULAR Scleroderma Research and Trial (EUSTAR): what has been achieved? Ann Rheum Dis 2014;73(2):324-7.

82. Khanna D, Furst DE, Allanore Y, Bae S, Bodukam V, Clements PJ, et al. Twenty-two points to consider for clinical trials in systemic sclerosis, based on EULAR standards. Rheumatology 
2015;54:144-51.

83. Lonzetti LS, Joyal F, Raynauld JP, Roussin A, Goulet JR, Rich E, et al. Updating The American College of Rheumatology preliminary classification criteria for systemic sclerosis: addition of severe nailfold capillaroscopy abnormalities markedly increases the sensitivity for limited scleroderma. Arthritis Rheum 2001;44(3):735-8.

84. Cutolo M, Matucci Cerinic M. Nailfold capillaroscopy and classification criteria for systemic sclerosis. Clin Exp Rheumatol 2007;25:663-5.

85. Jung P, Trautinger F. Capillaroscopy. J Dtsch Dermatol Ges 2013;11:731-6.

86. Cutolo M, Sulli A, Secchi ME, Paolino S, Pizzorni C. Nailfold capillaroscopy is useful for the diagnosis and follow-up of autoimmune rheumatic diseases. A future tool for the analysis of microvascular heart involvement? Rheumatology (Oxford) 2006;45(Suppl 4):iv43-6.

87. Baron M, Bell M, Bookman A, Buchignani M, Dunne J, Hudson M, et al. Office capillaroscopy in systemic sclerosis. Clin Rheumatol 2007;26:1268-74.

88. Hughes M, Moore T, O'Leary N, Tracey A, Ennis H, Dinsdale G, et al. A study comparing videocapillaroscopy and dermoscopy in the assessment of nailfold capillaries in patients with systemic sclerosis - spectrum disorders. Rheumatology 2015;54(8):1435-42.

89. Koenig M, Joyal F, Fritzler MJ, Roussin A, Abrahamowicz M, Boire G, et al. Autoantibodies and microvascular damage are independent predictive factors for the progression of Raynaud's phenomenon to systemic sclerosis: a twenty-year prospective study of 586 patients, with validation of proposed criteria for early systemic sclerosis. Arthritis Rheum 2008;58(12):3902-12.

90. Larche M. What's new in Scleroderma. [cited 2015 Oct 1]. Available from: http://staticl.squarespace.com/static 15280f5e9e4b0c046bfaad504/t/52decb0ee4b0fb2ead9eb0 ba/1390332686069/Whats+new+in+Scleroderma+8th+Jan+2014.pdf.

91. Steen VD. Autoantibodies in systemic sclerosis. Semin Arthritis Rheum 2005;35:35-42.

92. Karp DR, Marthandan N, Marsh SG, Ahn C, Arnett FC, Deluca DS, et al. Novel sequence feature variant type analysis of the HLA genetic association in systemic sclerosis. Hum Mol Genet 2009;19(4):707-19.

93. Arnett FC, Gourh P, Shete S, Ahn CW, Honey RE, Agarwal SK, et al. Major histocompability complex (MHC) class II alleles, haplotypes and epitopes which confer susceptibility or protection in systemic sclerosis: analyses in 1300 Caucasian, African-American and Hispanic cases and 1000 controls. Ann Rheum Dis 2010;69(5):822-7.

94. Loubiere LS, Lambert NC, Madeleine MM, Porter AJ, Mullarkey ME, Pang JM, et al. HLA allelic variants encoding DR11 in diffuse and limited systemic sclerosis in Caucasian women. Rheumatology 2005;44(3):318-22.

95. Fonseca C, Lindahl GE, Ponticos M, Sestini P, Renzoni EA,
Holmes AM, et al. A polymorphism in the CTGF promoter region associated with systemic sclerosis. $\mathrm{N}$ Engl J Med 2007;357:1210-20.

96. Beretta L, Rueda B, Marchini M, Santaniello A, Simeon CP, Fonollosa V, et al. Analysis of class II human leucocyte antigens in Italian and Spanish systemic sclerosis. Rheumatology 2012;51(1):52-9.

97. Manno R, Boin F. Immunotherapy of systemic sclerosis. Immunotherapy 2010;2(6):863-78.

98. Morita A, Kobayashi K, Isomura I, Tsuji T, Krutman J. Ultraviolet A1 (340-400 nm) phototherapy for scleroderma in systemic sclerosis. J Am Acad Dermatol 2000; 43:670-4.

99. Thompson AE, Pope JE. Calcium channel blockers for primary Raynaud's phenomenon: a meta-analysis. Rheumathology 2005;44:145-50.

100. Goundry B, Bell L, Langtree M, Moorthy A, BMJ. Diagnosis and management of Raynaud's phenomenon. BMJ 2012;344:e 289.

101. Rybalkin SD, Yan C, Bornfeldt K, Beavo J. Cyclic phosphodiesterases and regulation of smooth muscle function. Circ Res 2003;93:280-91.

102. Gore J, Silver R. Oral sildenafil for the treatment of Raynaud's phenomenon and digital ulcers secondary to systemic sclerosis. Ann Rheum Dis 2005;64:1387.

103. Rajagopalan S, Pfenninger D, Somers E, Kehrer C, Chakrabarti A, Mukherjee D, et al. Effects of Cilostazol in patients with Raynaud's syndrome. Am J Cardiol 2003;92:1310-5.

104. Wise RA, Wigley FM, White B, Leatherman G, Zhong J, Krasa H, et al. Efficacy and tolerability of a selective alpha(2c)adrenergic receptor blocker in recovery from cold-induced vasospasm in scleroderma patients: a single-center, doubleblind, placebo-controlled, randomized crossover study. Arthritis Rheum 2004;50(12):3994-4001.

105. Anderson ME, Moore TL, Hollis S, Jayson MIV, King TA, Herrick AL. Digital vascular response to topical glyceryl trinitrate, as measured by laser Doppler imaging, in primary Raynaud's phenomenon and systemic sclerosis. Rheumatology (Oxford) 2002;41:324-8.

106. Cukierman T, Elinav E, Korem M, Chajek- Shaul T. Low dose warfarin treatment for calcinosis in patients with systemic sclerosis. Ann Rheum Dis 2004;63:1341-3.

107. Sparsa A, Lesaux N, Kessler E, Bonnetblanc JM, Blaise S, Lebrun-Ly V, et al. Treatment of cutaneous calcinosis in CREST syndrome by extracorporeal shock wave lithotripsy. J Am Acad Dermatol 2005;53:S263-5.

108. Chamberlain AJ, Walker NP. Successful palliation and significant remission of cutanous calcinosis in CREST syndrome with carbon dioxide laser. Dermatol Surg 2003;29:968-70.

109. Saddic N, Miller JJ, Miller OF 3rd, Clarke JT. Surgical debridement painful fingertip calcinosis cutis in CREST syndrome. Arch Dermatol 2009;145:212-3. 


\section{CREST sindrom - ograničena varijanta sistemske skleroderme: prikaz slučaja i pregled literature}

\section{Sažetak}

Uvod. Sistemska skleroderma (SSc) je multisistemska bolest sa mikrovaskularnim abnormalnostima, autoimunskim poremećajima, pojačanom produkcijom i depozicijom kolagena i fibrozom kože i visceralnih organa. U osnovi radi se o sistemskoj sklerozi (SS) u kojoj skleroza zahvata i kožu. Prema najjednostavnijoj, mada ne i kompletnoj klasifikaciji, registruju se dve forme SSc: difuzna SSc i limitirana (raniji naziv akralna) SSc. Podtip limitirane SSc je CREST sindrom, čije su karakteristike: kalcinoza, Rejnoov fenomen (RF), ezofagealni dismotilitet, sklerodaktilija i teleangiektazije.

Prikaz slučaja. Prikazana je bolesnica sa sa tipičnom kliničkom slikom limitirane SSc i svim elementima CREST sindroma, kod koje je bolest počela u njenoj 43. godini i trajala 23 godine, sa postepenim razvojem bolesti u prvih desetak godina, počev od Rejnoovog fenomena, skleroze kože, kalcifikacija, telangiektazija do dismotiliteta ezofagusa. Primenjivana terapija je dovodila do privremenih poboljšanja, da bi konačno rezultirala smrtnim ishodom.

Dijagnoza je postavljena na osnovu kliničke slike i relevantnih dijagnostičkih procedura.

Diskusija. Akronim CREST potiče iz XX veka: Tibijerž (Thibierge) i Vajsenbah (Weissenbach) 1911. godine opisali su bolesnika sa kalcinozom kože, RF, sklerodaktilijom i telangiektazijama i bolest označili kao CRST sindrom. Vinterbauer (Winterbauer), kod četiri od svojih osam bolesnika sa CRST sindromom, 1964. godine registrovao je i dismotilitet jednjaka, a Freja (Frayha) i saradnici su 1973. godine, zbog česte pojave dismoliliteta jednjaka predložili akronim CREST. Dalje su opisivane razne kombinacije ovih kliničkih manifestacija, pa se govorilo o REST sindromu (bez kalcinoze), CRest, „Pure“ CREST (kada pacijent ima dva ili više simptoma CREST, ali nema dovoljno kriterijuma ni za limitiranu ni za difuznu sistemsku sklerozu), „Plus“ CREST (udruženost sa drugim formama sistemske skleroderme - limitiranom ili difuznom ili sa drugim autoimunskim bolestima). Kod naše pacijentkinje je postavljena dijagnozu CREST sindroma, sa ispunjenjem svih kriterijuma. Iako pojedini autori, zbog čestog odsustva pojedinih od naznačenih karakteristika bolesti smatraju da je ispravnije govoriti o limitiranoj kutanoj sklerodermi, te da je za dijagnozu dovoljno prisustvo dve od pet karakteristika, sindrom ne možemo odvojiti od sistemske skleroderme odnosno sistemske skleroze.

Kriterijumi za klasifikaciju sistemske skleroze koje je 2013. objavio Američki koledž za reumatologiju i Zajednička inicijativa Evropske lige protiv reumatizma (American College of Rheumatology (ACR)/ European League Against Rheumatism Collaborative Initiative), obuhvata 8 kriterijuma koji su vrednovani određenim brojem poena, tako da se definitivna dijagnoza SSc može postaviti ako je ukupan skor 9 ili više. To su: 1. zadebljanje prstiju obeju ruku proksimalno od metakarpofalangealnih zglobova (dovoljan kriterijum - 9 bodova); 2. zadebljanje prstiju, otok -2 poena, sklerodktilija - 4 poena; 3 lezije prstiju, ulceracije -2 poena, ispod ravni kože -3 poena; 4 . telangiektazije - 2 poena; 5 . abnormalni kapilari nokatnog zaslona - 2 poena; 6. zahvaćenost pluća: pulmonalna arterijska hipertenzija -2 poena, intersticijalna plućna bolest -2 poena; 7 . RF - 3 poena; 8. autoantitela tipična za sklerodermu (ACA anticentromerna, ili Scl-70 antitopomeraza 1 (TOPO I), ili anti-fibrillarin) -3 poena.

$\mathrm{U}$ novije vreme veliki broj autora radi na reviziji klasifikacije I kriterijuma uvodeći širok dijapazon elemenata koji su klinički i laboratorijski karakteristični za SSc, što će svakako doprineti preciznojoj dijagnostici, terapiji i prevenciji komplikacija bolesti. Kapilarna mikroskopija zaslona nokatne ploče (engl. nailfold capillary microsopy - NCM) je metoda kojom se određuje stepen kapilarne dilatacije, što je vrlo važno za ranu dijagnozu SSc. Kako kapilarne promene mogu da koreliraju sa visceralnim zahvatanjem, kapilaroskopija omogućava ranu dijagnozu organskih promena, što ima za rezultat rani početak terapije i prevenciju progresije i oštećenja organa. Ovom metodom se omogućava rana dijagnostika sistemske skleroze bez zahvatanja kože, kao i razlikovanje primarnog od sekundarnog 
RF i registrovanje progresije bolesti. Danas je najviše u upotrebi video-kapilaroskop. Ukoliko NCM poredimo sa dermoskopijom, snimci dobijeni pomoću NCM se mogu klasifikovati i mogu se ozbiljnije procenjivatii.

I pored brojnih novih saznanja, još uvek ne postoji terapijski algoritam koji može bitno promeniti prirodni tok bolesti. Od izuzetnog značaja je simptomatsko lečenje pacijenata. Lečenje SSc se planira zavisno od segmenta u patogenezi bolesti na koji se želi delovati, npr. na promene u vaskularnom sistemu, ili na povećanu sintezu kolagena ili izmenjenu imunsku reaktivnost. $\mathrm{Za}$ vazoaktivno lečenje primenjuju se: prostaciklin, niskomolekulski dekstran, stanozolol, nifedipin, kaptopril, ketanserin i plazmafereza. $\mathrm{Na}$ produkciju kolagena deluju: D-penicilinamin, pentoksifilin, faktor koagulacije XIII, ciklofenil, kolhicin, griseofulvin, 13cis retinoična kiselina. Za imunsku terapiju koriste se: prednizon, ciklofosfamid, azatioprim, ciklosporin.

Hinhklif (Hinchcliff) i Varga su dali pregled lečenja organ-specifičnih komplikacija kod SSc:

- Rejnoov fenomen - alfa adrenergični blokatori, blokatori angiotenzin II receptora, dugodelujući (longacting) blokatori kalcijumovih kanala (dihidropiridini), pentoksifilin (trental), blokade stelatnih gangliona, digitalna simpaktetomija;

- fibroza kože - imunomodulatorni lekovi (d-penicilinamin, mikofenolat mofetil, ciklofosfamid;

- gastro-ezofagealni refluks - antacidi, H2 antihistaminici, inhibitori protonske pumpe;

- intestinalni dismotilitet ili bakterijska infekcija - antibiotici, korekcija nutricione deficijencije, promotilitentni agensi;

- pulmonalnafibrozailialveolitis -imunomodulatori, inicijalna terapija sa oralnim ili intravenoznim ciklofosfamidom, terapija održavanja - azatioprin;

- pulmonalna arterijska hipertenzija diuretici, inhibitori endotelin-1 receptora (bosentan), kiseonik, inhibitori fosfodiesteraze-5 (sildenafil), analozi prostaciklina (epoprostenol, treptostanil, iloprost), warfarin (kod rekurentne pulmonalne tromboembolične bolesti);

- sklerodermna reanalna kriza - dijaliza, kratkodelujući inhibitori angiotenzin-konvertujućeg enzima;

Mano(Manno) iBoinsudalipregled imunomodultora koji se primenjuju kod SSc prema kategorijama, nazivu leka, mehanizmu dejstva i preporučenim dozama:

- neselektivna imunoterapija - ciklofosfamid, mikofenolat mofetil, azatioprin, metotreksat;

- T-ćelijska ciljana imunoterapija - ciklosporin A, antitimocitni globulin, ekstrakorporalna fotofereza, sirolimus (rapamicin);

- B-ćelijska ciljana imunoterapija - rituksimab;

- intravenozni imunoglobulini;

- biološka imunoterapija - inhibitori TNF alfa, infiksimab;

- antifibrotična terapija - CAT-192, imatinib mesilat;

- ćelijski bazirana (cell-based) imunotrapija transplantacija autolognih i alogenih stem ćelija.

Kliničko poboljšanje kod bolesnika sa SSc dobijeno je u pojedinim slučajevima primenom fototerapije UVA 1 zracima.

Zaključak. Podelom sistemske skleroderme u dve grupe oboljenja, grupu difuzne i grupu limitirane skleroderme, sa CREST sindromom kao pripadnikom limitirane skleroderme, mora se imati na umu da obe grupe obuhvataju različite kliničke varijante sistemske skleroze, koje zahvataju iste organe, dovode do istih laboratorijskih odstupanja i pokazuju tok koji nije nepromenljiv, što je prikazano i u slučaju opisanom u ovom radu. Prikazana je bolesnica sa tipičnom kliničkom slikom limitirane sistemske skleroze i svim simptomima CREST sindroma, kod koje je bolest trajala 23 godine, a primenjivana terapija je dovodila do privremenih poboljšanja, da bi konačno rezultirala smrtnim ishodom.

\section{Ključne reči}

Sistemska skleroderma; CREST sindrom; Znaci i simptomi; Dijagnoza; Prikazi slučajeva; Pregled literature 